\title{
Influence of Biofield Energy Treatment on Isotopic Abundance Ratio in Aniline Derivatives
}

\author{
Mahendra Kumar Trivedi ${ }^{1}$, Alice Branton ${ }^{1}$, Dahryn Trivedi ${ }^{1}$, Gopal Nayak ${ }^{1}$, Gunin Saikia ${ }^{2}$ and Snehasis Jana ${ }^{2 *}$ \\ ${ }^{1}$ Trivedi Global Inc., 10624 S Eastern Avenue Suite A-969, Henderson, NV 89052, USA \\ ${ }^{2}$ Trivedi Science Research Laboratory Pvt. Ltd., Hall-A, Chinar Mega Mall, Chinar Fortune City, Hoshangabad Rd., Bhopal, Madhya Pradesh, India
}

\begin{abstract}
The aim of this study was to evaluate the impact of biofield energy treatment on the isotopic abundance of ${ }^{13} \mathrm{C} /{ }^{12} \mathrm{C}$ or ${ }^{2} \mathrm{H} /{ }^{1} \mathrm{H}$ or ${ }^{15} \mathrm{~N} /{ }^{14} \mathrm{~N} \equiv(\mathrm{PM}+1) / \mathrm{PM}$ in aniline; and $(\mathrm{PM}+1) / \mathrm{PM}$ and ${ }^{81} \mathrm{Br} /{ }^{79} \mathrm{Br} \equiv(\mathrm{PM}+2) / \mathrm{PM}$ in 4-bromoaniline using Gas Chromatography-Mass Spectrometry (GC-MS). Aniline and 4-bromoaniline samples were divided into two parts: control and treated. The control part remained as untreated, while the treated part was subjected to Mr. Trivedi's biofield energy treatment. The treated samples were subdivided in three parts named as T1, T2, and T3 for aniline and four parts named as T1, T2, T3, and T4 for 4-bromoaniline. The GC-MS data revealed that the isotopic abundance ratio of $(\mathrm{PM}+1) / \mathrm{PM}$ in aniline was increased from $-40.82 \%, 30.17 \%$ and $73.12 \%$ in $\mathrm{T} 1$, $\mathrm{T} 2$ and $\mathrm{T} 3$ samples respectively. However in treated samples of 4-bromoaniline the isotopic abundance ratio of PM+1/PM was increased exponentially from $-4.36 \%$ (T1) to $368.3 \%$ (T4) as compared to the control. A slight decreasing trend of the isotopic ratio of (PM+2)/ PM in 4-bromoaniline was observed after biofield energy treatment. The GC-MS data suggests that the biofield energy treatment has significantly increased the isotopic abundance of ${ }^{2} \mathrm{H},{ }^{13} \mathrm{C}$ and ${ }^{15} \mathrm{~N}$ in the treated aniline and 4-bromoaniline, while slight decreased the isotopic abundance of ${ }^{81} \mathrm{Br}$ in treated 4-bromoaniline as compared to their respective control.
\end{abstract}

Keywords: Biofield energy treatment; Aniline; Gas chromatographyMass spectrometry; 4-Bromoaniline; Isotopic abundance

\section{Abbreviations}

PM: Primary Molecule; $\mathrm{PM}+1$ : Isotopic Molecule either for ${ }^{13} \mathrm{C} /{ }^{12} \mathrm{C}$ or ${ }^{2} \mathrm{H} /{ }^{1} \mathrm{H}$ or ${ }^{15} \mathrm{~N} /{ }^{14} \mathrm{~N}$; PM+2: Isotopic molecule for ${ }^{81} \mathrm{Br}^{179} \mathrm{Br}$

\section{Introduction}

Aniline and its derivatives are widely present in natural products, vitamins, amino acids and are being used as an antioxidants, and in the production of dyes and pesticides [1,2] although these compounds are hazardous to the environment and humans, including its acute toxicity, neurotoxicity, reproductive and developmental toxicity. Aniline and 4-bromoaniline have been used as an intermediate in the synthesis of several pharmaceutical drugs (plasmochin, and pamaquine) $[3,4]$, antioxidants ( $p$-phenylenediamine and octyl diphenylamine), and antiseptic agents [5]. Diazo product of these compounds can be used for the production of azo dye in the textile industry. Some other chemical intermediates like $p$-phenylenediamine, 2-chloro4-nitroaniline, 2,6-dichloro-4-nitroaniline etc. are also prepared using $p$-bromoaniline/aniline as a starting material [6]. Aromatic secondary amines can be readily oxidized and are used as antioxidants in rubber industries [7]. Amines and their salts are also known to possess bactericidal, fungicidal and algaecidal activities [8]. Despite such practical importance, aromatic amines are prone to oxidation at ambient conditions, the $\mathrm{N}-\mathrm{H}$ bond cleavage starts the most common photochemical process in N-H containing aromatic compounds and reduces its practical importance $[9,10]$.

The stability issue associated with the structural properties of aromatic amine derivatives can be addressed by an alternative mean. Nowadays, biofield energy treatment is known to alter the various properties of living and non-living things [11-13]. The American College of Obstetricians and Gynecologists (ACOG) defines biofields as "energy fields that purportedly surround and penetrate the human body". Human has the ability to harness the energy from environment/ universe and can transmit into any object around the Universe. The object(s) always receive the energy and responded into useful way. This process is known as biofield treatment [14]. National Centre for Complementary and Alternative Medicine (NCCAM) have reported that biofield energy therapies are commonly used to promote the health and healing is very popular in subgroup of energy medicine among complementary medicines [15-17]. People in western countries practice biofield healing therapy as certain form of Complementary and Alternative Medicine (CAM) [18]. Mr. Trivedi's unique biofield treatment is also called as The Trivedi Effect. The impact of the Trivedi Effect has been well studied in various research fields like material sciences [19,20], agricultural [21,22], and microbiology research [23]. Hence, based on the outstanding results achieved by the biofield energy treatment an attempt was made to evaluate the effect of biofield energy treatment on the isotopic abundance ratio of ${ }^{13} \mathrm{C} /{ }^{12} \mathrm{C}$ or ${ }^{2} \mathrm{H} /{ }^{1} \mathrm{H}$ or ${ }^{15} \mathrm{~N} /{ }^{14} \mathrm{~N}$ $(\mathrm{PM}+1 / \mathrm{PM})$ and ${ }^{81} \mathrm{Br} /{ }^{79} \mathrm{Br}(\mathrm{PM}+2 / \mathrm{PM})$ in aniline and 4 -bromoaniline.

\section{Experimental}

\section{Materials}

Aniline and 4-bromoaniline were procured from Qualigens, India and S. D. Fine Chem. Ltd., India, respectively.

\section{Biofield energy treatment modalities}

Aniline and 4-bromoaniline were taken in this experiment for biofield energy treatment. The compounds were divided into two parts named as control and treated. No treatment was given to the control set. The treated group was handed over to Mr. Trivedi for biofield energy treatment in sealed pack under standard laboratory conditions. Mr. Trivedi provided the treatment through his energy transmission process to the treated group without touching the sample. After treatment, the treated samples were stored at standard laboratory conditions for GC-

*Corresponding author: Snehasis Jana, Trivedi Science Research Laboratory Pvt. Ltd., Hall-A, Chinar Mega Mall, Chinar Fortune City, Hoshangabad Rd. Bhopal-462 026, Madhya Pradesh, India, Tel: +91-755-666-0006; E-mail: publication@trivedisrl.com

Received September 09, 2015; Accepted September 29, 2015; Published October 02, 2015

Citation: Trivedi MK, Branton A, Trivedi D, Nayak G, Saikia G, et al. (2015) Influence of Biofield Energy Treatment on Isotopic Abundance Ratio in Aniline Derivatives. Mod Chem appl 3: 168. doi:10.4172/2329-6798.1000168

Copyright: ( $) 2015$ Trivedi MK, et al. This is an open-access article distributed under the terms of the Creative Commons Attribution License, which permits unrestricted use, distribution, and reproduction in any medium, provided the original author and source are credited. 
MS analysis as per the standard operating protocol. The control and treated samples were characterized using Gas Chromatography-Mass Spectrometry (GC-MS). The experimental results in treated groups were analyzed and compared with the control set.

\section{GC-Mass spectrometry}

GC-MS analysis was done on Perkin Elmer/auto system XL with Turbo mass, USA. The GC/MS was performed in a silica capillary column. It was equipped with a quadrupole detector with pre-filter, one of the fastest, widest mass ranges available for any GC/MS. The mass spectrometer was operated in an Electron Ionization (EI) positive/ negative, and chemical ionization mode at the electron ionization energy of $70 \mathrm{eV}$. Mass range: 20-620 Daltons ( $\mathrm{amu}$ ), stability: $\pm 0.1 \mathrm{~m} / \mathrm{z}$ mass accuracy over 48 hours. The identification of analytes was done by retention time and by a comparison of the mass spectra of identified substances with references.

The treated sample was divided into three parts in aniline as T1, T2, and T3 and four parts in 4-bromoaniline as T1, T2, T3, and T4 for GCMS analysis. The mass spectrum from GC-MS was obtained in the form of $\%$ abundance vs. mass to charge ratio $(\mathrm{m} / z)$. The isotopic abundance ratio ${ }^{13} \mathrm{C} /{ }^{12} \mathrm{C}$ or ${ }^{2} \mathrm{H} /{ }^{1} \mathrm{H}$ or ${ }^{15} \mathrm{~N} /{ }^{14} \mathrm{~N}(\mathrm{PM}+1 / \mathrm{PM})$ and ${ }^{81} \mathrm{Br}{ }^{179} \mathrm{Br}(\mathrm{PM}+2 / \mathrm{PM})$ was expressed by its deviation in the treated samples as compared to the control. The percentage change in isotopic ratio $(\mathrm{PM}+1 / \mathrm{PM})$ and $(\mathrm{PM}+2 /$ $\mathrm{PM}$ ) were calculated on a percentage scale from the following formula:

Percent changein isotopic abundance ratio $(\mathrm{PM}+1 / \mathrm{PM})=\frac{R_{\text {Treated }}-R_{\text {Control }}}{R_{\text {Conrol }}} \times 100$

Where, $R_{\text {Treated }}$ and $R_{\text {Control }}$ are the ratio of intensity at $(\mathrm{PM}+1)$ to $\mathrm{PM}$ in mass spectra of treated and control samples, respectively.

\section{Results and Discussion}

\section{GC-MS data}

GC-MS of aniline: The mass spectra of control and treated samples (T1, T2, and T3) are presented in Figures 1 and 2. Mass spectra showed PM peak at $m / z=93$ in control and all the treated samples of aniline. The intensity ratio of $\mathrm{PM}+1$ (i.e., $m / z=94$ ) and $\mathrm{PM}$ (i.e., $m / z=93$ ) peaks are presented in Table 1. There were three major peaks observed in control sample i.e., at $m / z=93,65$ and 52 due to fragmentation of aniline, corresponded to the following ions: $\mathrm{C}_{6} \mathrm{H}_{7} \mathrm{~N}^{+}, \mathrm{C}_{5} \mathrm{H}_{5}{ }^{+}$(pentadine), and $\mathrm{C}_{4} \mathrm{H}_{4}{ }^{+}$(buten-3-yne) respectively. The peaks at $\mathrm{m} / z=93,65$ and 52 in control sample were well matched with the previously reported GCMS data [24]. The treated aniline samples (T1-T3) were fragmented in a different fashion as compared to the control and exhibited five major peaks in the mass spectrum with diverse intensities. For instance, peaks at $m / z=65,52,39$, and 28 were observed may be due to PM breaking up of treated aniline to pentadine, buten-3-yne, propyne and ethene radicals respectively.

However, a significant alteration in isotopic abundance ratio of $(\mathrm{PM}+1 / \mathrm{PM})$ was observed for treated aniline as compared to the control. The isotopic abundance ratio in control and treated aniline was calculated and presented in the Table 1, also the change in isotopic abundance ratio of $(\mathrm{PM}+1) / \mathrm{PM}$ for the treated samples are shown in Figure 3. It is seen from the Figure 3 that the isotopic abundance ratio of $\mathrm{PM}+1 / \mathrm{PM}$ of treated aniline was increased by $30.17 \%$ in $\mathrm{T} 2$ and $73.12 \%$ in T3, and decreased to $40.82 \%$ in T1 as compared to the control. The increased isotopic abundance ratio of $(\mathrm{PM}+1 / \mathrm{PM})$ in treated aniline samples may increase the effective mass $(\mu)$ and binding energy due to heavier isotopes i.e., ${ }^{13} \mathrm{C}$ or ${ }^{2} \mathrm{H}$ or ${ }^{15} \mathrm{~N}$.

GC-MS spectra of 4-bromoaniline: The PM peak was observed at $m / z=171$ in both control and treated samples with different intensity
(Figures 4 and 5). The base peak was observed at $m / z=65$ in control and treated (T1) sample of 4-bromoaniline, however for other treated samples, T2, T3, and T4 the molecular ion peak i.e., at $m / z=171$ was the base peak. The intensity ratio of $\mathrm{PM}$ peak and $\mathrm{PM}+1$ peak are given in Table 2. Total four major peaks at $m / z=171,92,65$, and 39

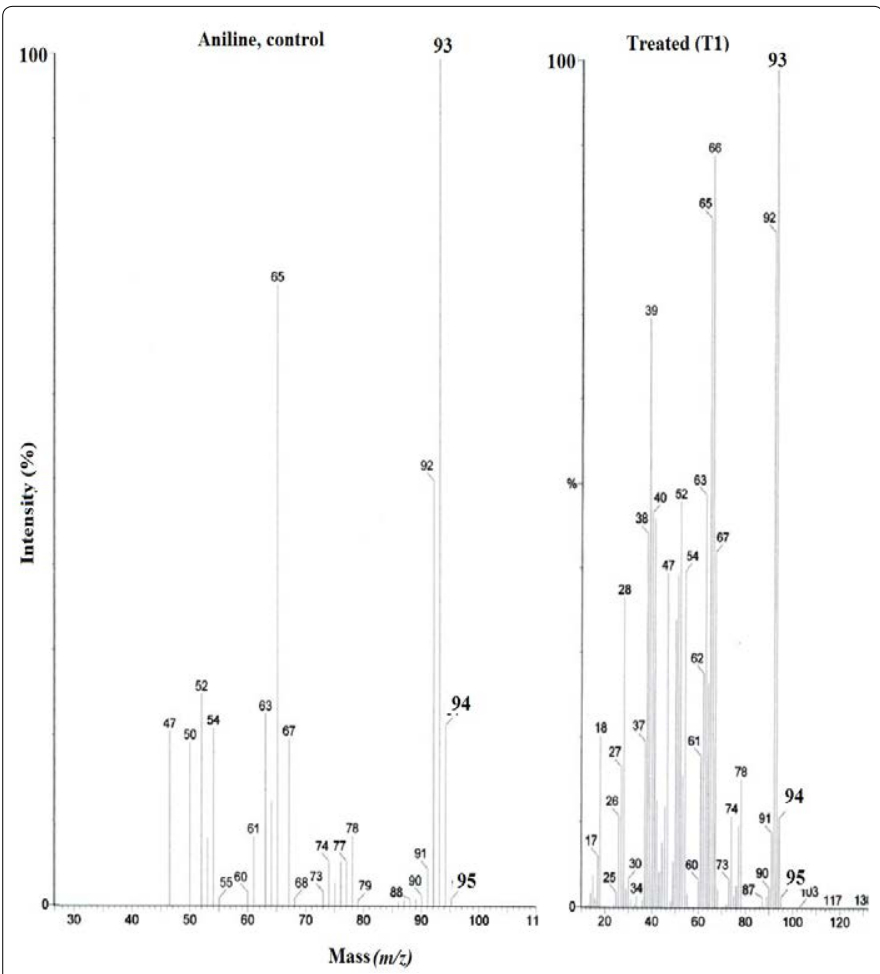

Figure 1: GC-MS spectra of control and treated (T1) samples of aniline.

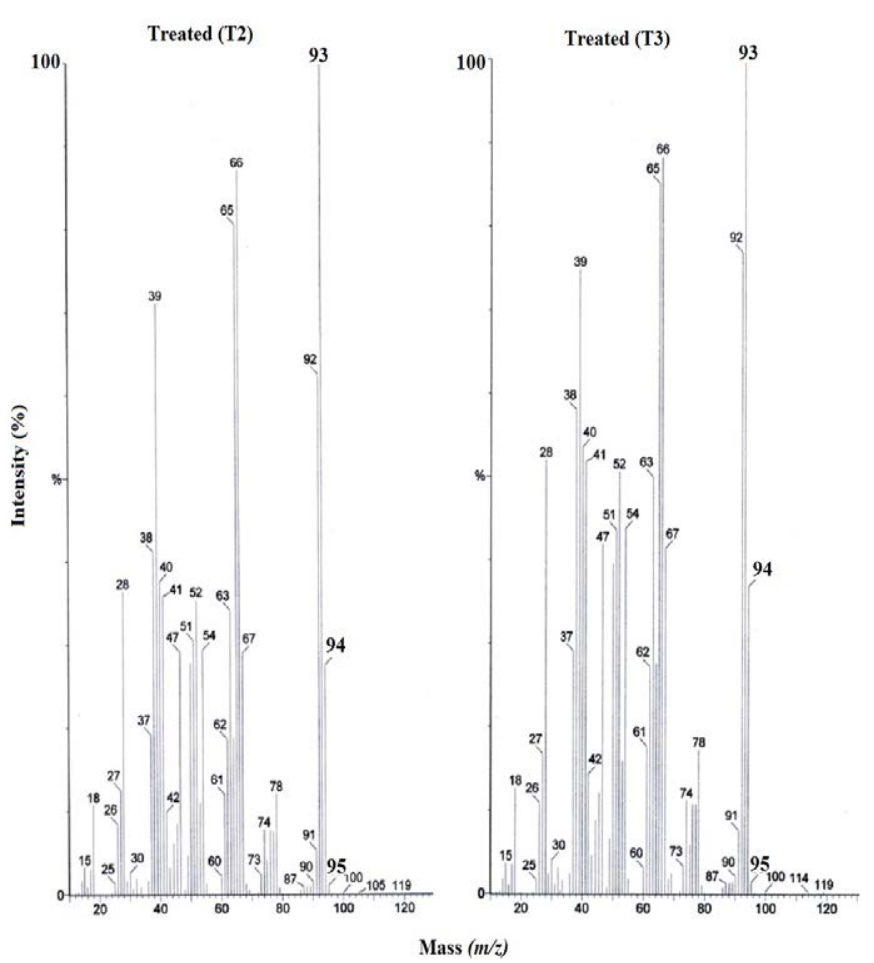

Figure 2: GC-MS spectra of treated (T2 and T3) samples of aniline. 


\begin{tabular}{|l|c|c|c|c|}
\hline \multirow{2}{*}{ Parameter } & \multirow{2}{*}{ Control } & \multicolumn{3}{|c|}{ Treated } \\
\cline { 3 - 5 } & & T1 & T2 & T3 \\
\hline Peak intensity at $m / z=(P M)$ & 100 & 100 & 100 & 100 \\
\hline Peak intensity at $m / z=(P M+1)$ & 21.21 & 12.55 & 27.61 & 36.72 \\
\hline
\end{tabular}

Table 1: GC-MS isotopic abundance analysis result of aniline.

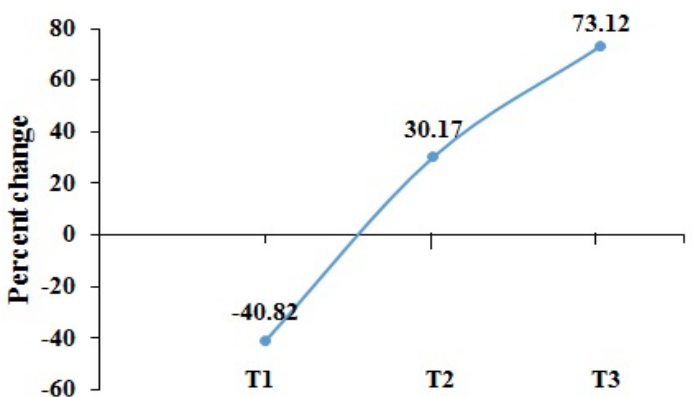

Figure 3: Percent change in isotopic abundance ratio of (PM+1/PM) in aniline under biofield energy treatment.

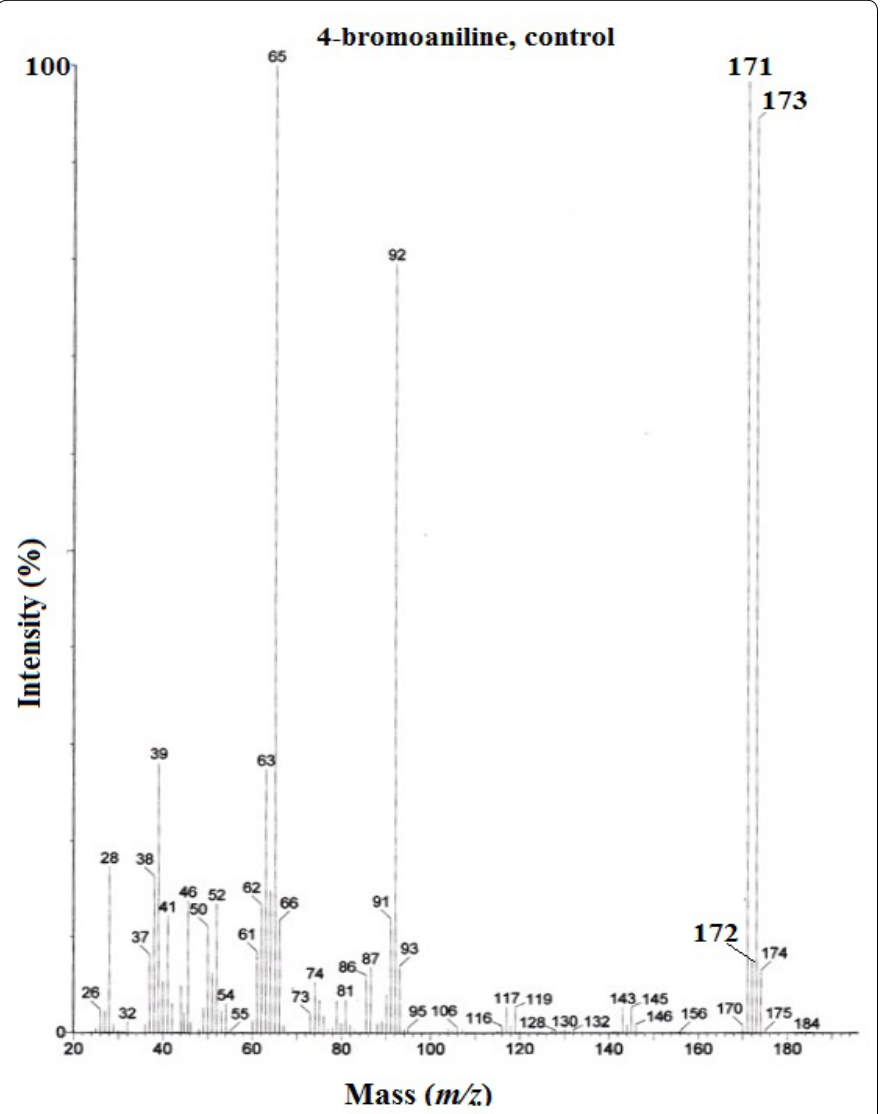

Figure 4: GC-MS spectrum of control sample of 4-bromoaniline.

were observed in the control sample of 4-bromoaniline may due to the fragmentation of 4-bromoaniline to $\mathrm{C}_{6} \mathrm{H}_{6} \mathrm{BrN}^{+} \mathrm{C}_{6} \mathrm{H}_{6} \mathrm{~N}^{+}, \mathrm{C}_{5} \mathrm{H}_{5}^{+}$, and $\mathrm{C}_{3} \mathrm{H}_{3}{ }^{+}$ions, respectively. Further treated samples, T1, T2, and T3 of 4-bromoaniline were fragmented in a similar way as the control sample but T4 sample fragmented to give two extra peaks at $m / z=52$ and 42 which could be due to the $\mathrm{C}_{4} \mathrm{H}_{4}{ }^{+}$and $\mathrm{C}_{3} \mathrm{H}_{6}{ }^{+}$ions, respectively. Peak at $m / z=92$ was seen in both control and treated samples may due to the initial fragmentation of 4 -bromoaniline to aniline $\mathrm{e}^{+}$Peaks at $m / z=65$ and 39 were observed may be due to the formation of cyclopentadiene and propyne from the ring opening reaction of 4-bromoaniline. The extra peaks were observed at $m / z=52$ and 42 in treated (T4) sample of 4-bromoaniline, which may be due to the formation of but-1-en-3yne and propene. Fragmentation pattern and number of fragmented peaks of control 4-bromoaniline molecules were well matched with the literature report [25]. The isotopic abundance ratio of $(\mathrm{PM}+1 / \mathrm{PM})$ and $(\mathrm{PM}+2 / \mathrm{PM})$ of control and treated 4-bromoaniline are shown in the Table 2 and plotted in Figure 6. The isotopic abundance ratio of $\mathrm{PM}+1 /$ $\mathrm{PM}$ of treated 4-bromoaniline was increased exponentially up to $368.3 \%$ from $\mathrm{T} 1$ to $\mathrm{T} 4$ samples $(\mathrm{T} 1=-4.36 \%, \mathrm{~T} 2=70.78 \% \mathrm{~T} 3=140.55 \%$, and $\mathrm{T} 4=368.3 \%)$. However, the isotopic abundance ratio of $\mathrm{PM}+2 /$ $\mathrm{PM}$ was decreased gradually to $4.65 \%(\mathrm{~T} 1=-0.5 \%, \mathrm{~T} 2=-0.64 \% \mathrm{~T} 3=$ $-3 \%$, and $\mathrm{T} 4=-4.65 \%)$. The change in $\mathrm{PM}+2 / \mathrm{PM}$ may be due to the presence of bromine in 4-bromoaniline. It is reported that the isotope fractionation for bromine is slower than chlorine, carbon, hydrogen and nitrogen in hydrophobic environment which is much dependent on the reaction path (kinetic) of organohalogen compounds [26] and slow depletion of $\mathrm{PM}+2 / \mathrm{PM}$ ratio (4.65\%) is observed.

Atoms taking part in chemical bonds with higher isotopic number have higher binding energy with increased effective mass $(\mu)$ and vice versa. Thus, the increased isotopic abundance ratio of ${ }^{13} \mathrm{C} /{ }^{12} \mathrm{C}$ or ${ }^{2} \mathrm{H} /{ }^{1} \mathrm{H}$ $(\mathrm{PM}+1 / \mathrm{PM})$ in both the compounds (aniline and 4-bromoaniline) might increase the effective mass and binding energy after biofield energy treatment that may enhance the stability of aniline derivatives significantly. However the isotopic abundance ratio of ${ }^{81} \mathrm{Br} /{ }^{79} \mathrm{Br}$ $(\mathrm{PM}+2 / \mathrm{PM})$ was decreased slightly in 4-bromoaniline. As the isotopic abundance of ${ }^{81} \mathrm{Br}$ is $49.31 \%$ and ${ }^{79} \mathrm{Br}$ is $50.69 \%$, so this minor depletion $(-4.65 \%)$ in ${ }^{81} \mathrm{Br}$ in treated 4 -bromoaniline may not affect the stability significantly. However the increased isotopic abundance ratio $(\mathrm{PM}+1 /$ PM) may reasonably increase the number of heavier isotopes (i.e., ${ }^{2} \mathrm{H}$, ${ }^{13} \mathrm{C}$ and ${ }^{15} \mathrm{~N}$ ) in the molecule after biofield energy treatment. Some probable bonds are presented in Table 3 that might present in aniline and 4-bromoaniline such as ${ }^{12} \mathrm{C}-{ }^{12} \mathrm{C},{ }^{1} \mathrm{H}-{ }^{12} \mathrm{C},{ }^{13} \mathrm{C}-{ }^{12} \mathrm{C},{ }^{2} \mathrm{H}-{ }^{12} \mathrm{C},{ }^{1} \mathrm{H}-{ }^{13} \mathrm{C}$, ${ }^{12} \mathrm{C}-{ }^{81} \mathrm{Br},{ }^{13} \mathrm{C}-{ }^{14} \mathrm{~N}$, and ${ }^{2} \mathrm{H}-{ }^{15} \mathrm{~N}$ after the biofield energy treatment. The effective mass of various chemical bonds were calculated and presented in Table 3. The result showed that $\mu$ of normal ${ }^{12} \mathrm{C}-{ }^{79} \mathrm{Br},{ }^{12} \mathrm{C}-{ }^{12} \mathrm{C},{ }^{12} \mathrm{C}-{ }^{14} \mathrm{~N}$ and ${ }^{1} \mathrm{H}_{-}{ }^{12} \mathrm{C}$ bonds were $10.41,6,6.46$ and $0.923 \mathrm{amu}$, respectively. It showed that effective mass is higher in case of heavier isotope (i.e., ${ }^{12} \mathrm{C}-{ }^{81} \mathrm{Br}=10.45,{ }^{12} \mathrm{C}-{ }^{13} \mathrm{C}=6.24,{ }^{13} \mathrm{C}-{ }^{14} \mathrm{~N}=6.74$ and $\left.{ }^{2} \mathrm{H}-{ }^{12} \mathrm{C}=1.71 \mathrm{amu}\right)$. So localized enrichment of heavier isotope may occur in this process, which may lead to significant change in energy of the isotope substituted bonds. It may enhance the bond strength, stability, and binding energy of aniline and 4-bromoaniline molecules.

\section{Conclusion}

In summary, aniline and 4-bromoaniline were studied under the influence of biofield energy treatment and significant changes were observed in isotopic abundance as compared to the control sample. The increases in isotopic abundance ratio of ${ }^{13} \mathrm{C} /{ }^{12} \mathrm{C}$ or ${ }^{2} \mathrm{H} /{ }^{1} \mathrm{H}$ or ${ }^{15} \mathrm{~N} /{ }^{14} \mathrm{~N}$ $(\mathrm{PM}+1 / \mathrm{PM})$ was up to $73.12 \%$ and $368.3 \%$ in treated samples of aniline and 4-bromoaniline respectively. However, in treated samples of 4-bromoaniline, the isotopic abundance ratio of ${ }^{81} \mathrm{Br} /{ }^{79} \mathrm{Br}(\mathrm{PM}+2 / \mathrm{PM})$ was decreased by $4.65 \%$. The alteration of isotopic ratio after biofield energy treatment has a significant impact on the bond energies and the chemical reactivity of the molecules. Bond strength may be increased by increasing the effective mass $(\mu)$, of the atoms which consequently increases the binding energy. The decreased number of ${ }^{81} \mathrm{Br}$ in the treated samples might not affect much on the total effective masses of the respective bonds as the number of altered atoms are negligible as compared to the abundance of the $\mathrm{PM}+1$ isotopes. It is assumed from 


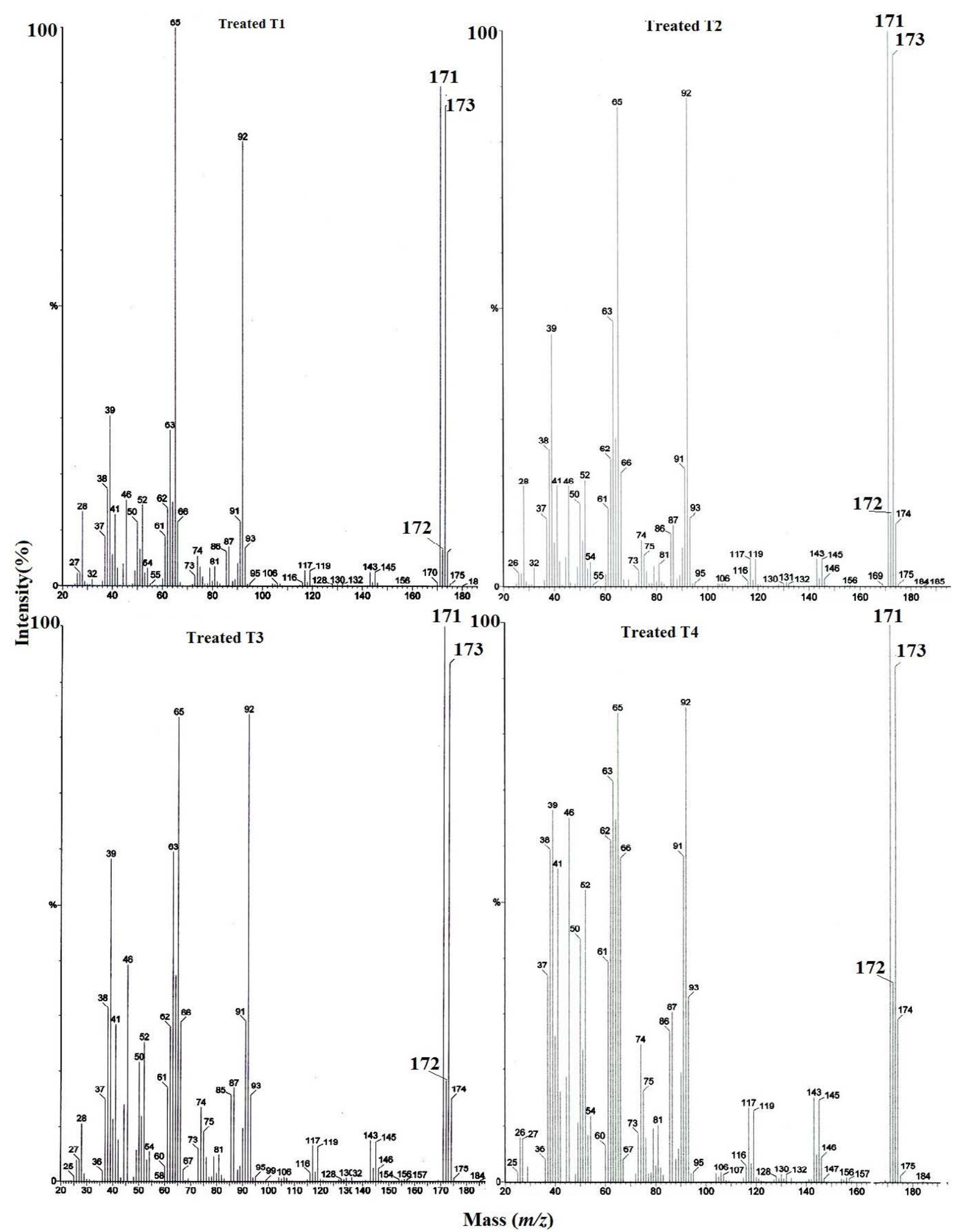

Figure 5: GC-MS spectra of treated samples of 4-bromoaniline. 
Citation: Trivedi MK, Branton A, Trivedi D, Nayak G, Saikia G, et al. (2015) Influence of Biofield Energy Treatment on Isotopic Abundance Ratio in Aniline Derivatives. Mod Chem appl 3: 168. doi:10.4172/2329-6798.1000168

Page 5 of 5

\begin{tabular}{|l|c|c|c|c|c|}
\hline \multirow{2}{*}{ Parameter } & \multirow{2}{*}{ Control } & \multicolumn{4}{|c|}{ Treated } \\
\cline { 3 - 6 } & & T1 & T2 & T3 & T4 \\
\hline Peak intensity at $m / z=(P M)$ & 98 & 89.64 & 100 & 100 & 100 \\
\hline Peak intensity at $m / z=(P M+1)$ & 7.5 & 6.56 & 13.07 & 18.41 & 35.84 \\
\hline Peak intensity at $m / z=(P M+2)$ & 94.42 & 85.93 & 95.73 & 93.45 & 91.86 \\
\hline
\end{tabular}

Table 2: GC-MS isotopic abundance analysis result of 4-bromoaniline.

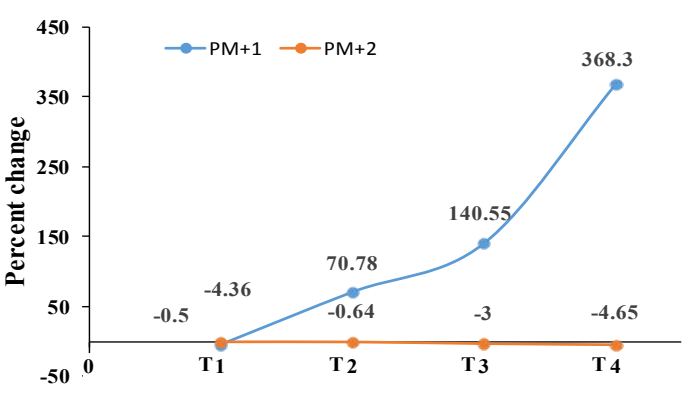

Figure 6: Percent change in isotopic abundance ratio of $(P M+1) / P M$ and $(\mathrm{PM}+2) / \mathrm{PM}$ of 4-bromoaniline under biofield energy treatment.

\begin{tabular}{|c|c|c|}
\hline Isotopes bond & Isotope type & $\begin{array}{c}\text { Reduced mass }(\boldsymbol{\mu}) \\
\mathbf{m}_{\mathbf{A}} \mathbf{m}_{\mathbf{B}} /\left(\mathbf{m}_{\mathbf{A}} \mathbf{+} \mathbf{m}_{\mathrm{B}}\right)\end{array}$ \\
\hline${ }^{12} \mathrm{C}-{ }^{12} \mathrm{C}$ & lighter & 6.00 \\
\hline${ }^{13} \mathrm{C}-{ }^{-12} \mathrm{C}$ & heavier & 6.26 \\
\hline${ }^{1} \mathrm{H}-{ }^{12} \mathrm{C}$ & lighter & 0.923 \\
\hline${ }^{1} \mathrm{H}-{ }^{13} \mathrm{C}$ & heavier & 0.929 \\
\hline${ }^{2} \mathrm{H}-{ }^{12} \mathrm{C}$ & heavier & 1.04 \\
\hline${ }^{14} \mathrm{~N}-{ }^{13} \mathrm{C}$ & heavier & 6.5 \\
\hline${ }^{15} \mathrm{~N}-{ }^{-12} \mathrm{C}$ & heavier & 1.71 \\
\hline${ }^{14} \mathrm{~N}-{ }^{13} \mathrm{C}$ & heavier & 1.71 \\
\hline${ }^{79} \mathrm{Br}-{ }^{12} \mathrm{C}$ & lighter & 10.41 \\
\hline${ }^{79} \mathrm{Br}-{ }^{13} \mathrm{C}$ & heavier & 11.16 \\
\hline${ }^{81} \mathrm{Br}-{ }^{12} \mathrm{C}$ & heavier & 10.45 \\
\hline${ }^{14} \mathrm{~N}-{ }^{2} \mathrm{H}$ & heavier & 1.75 \\
\hline${ }^{15} \mathrm{~N}-{ }^{1} \mathrm{H}$ & heavier & 0.94 \\
\hline
\end{tabular}

Table 3: Possible isotopic bonds in treated aniline and 4-bromoaniline. Where, $m_{A}$ : Mass of an atom $A, m_{B}$ : Mass of an atom $B$, Here A may be $C$ (carbon) or $H$ (hydrogen) and so on

the results that the increased isotopic abundance ratio of $\mathrm{PM}+1$ after Mr. Trivedi's biofield energy treatment on aniline and 4-bromoaniline molecules are enough to maintain the stability of bonds, which could result in the reduction of decomposition and photo oxidation reactions initiated by heat, light and molecular oxygen in aniline and 4-bromoaniline.

\section{Acknowledgement}

The authors would like to acknowledge the whole team from the Sophisticated Analytical Instrument Facility (SAIF), Nagpur for providing the instrumental facility. We are very grateful for the support from Trivedi Science, Trivedi Master Wellness and Trivedi Testimonials in this research work.

\section{References}

1. Travis AS (2007) Manufacture and uses of the anilines: A vast array of processes and products. Patai's Chemistry of Functional Groups. Wiley, New York, USA

2. Kavitha E, Sundaraganesan N, Sebastin S (2010) Molecular structure vibrational spectroscopic and HOMO, LUMO studies of 4-nitroaniline by density functional method. Indian J Pure Appl Phys 48: 20-30.

3. Shanker V, Rayabandla SM, Kumavath RN, Chintalapati S, Chintalapati R (2006) Light-dependent transformation of aniline to indole esters by the purple bacterium Rhodobacter sphaeroides OU5. Curr Microbiol 52: 413-417.
4. Patel SR (2012) Study of the photosensitized reaction of the isomeric fluoroanilines with methylene blue in the visible light.

5. Himaja M, Das P, Rout PK, Sharma S, Munirajasekhar D, et al. (2012) Synthesis docking and antioxidant activity of some NSAID derivatives of amines. IJRAP 3: $548-551$.

6. Fierz-David HE, Blangey $L$ (1949) Fundamental processes of dye chemistry. $\left(5^{\text {th }}\right.$ edn), Interscience publishers, Inc., New York.

7. Kasthuri J, Santhanalakshmi J, Rajendiran N (2008) Antipyrilquinoneimine dye formation by coupling aniline derivatives with 4-aminoantipyrine in the presence of ruthenium nanoparticles. J Iran Chem Soc 3: 436-444.

8. Kareem MT, Ibrahim KA (2011) Synthesis and characterization of some anilines oxidative coupling products. Tikrit J Pure Sci 16: 42-49.

9. de Mayo P (1980) Rearrangement in Ground and Excited States. (3 ${ }^{\text {rd }}$ edn), Academic Press, New York, USA.

10. Tseng CM, Dyakov YA, Huang CL, Mebel AM, Lin SH, et al. (2004) Photoisomerization and photodissociation of aniline and 4-methylpyridine. J Am Chem Soc 126: 8760-8768.

11. Trivedi MK, Patil S, Tallapragada RM (2014) Atomic, Crystalline and Powder Characteristics of Treated Zirconia and Silica Powders. J Material Sci Eng 3 : 144

12. Shinde V, Sances F, Patil S, Spence A (2012) Impact of biofield treatment on growth and yield of lettuce and tomato. Aust J Basic \& Appl Sci 6: 100-105.

13. Trivedi MK, Patil S, Shettigar H, Gangwar M, Jana S (2015) Antimicrobial sensitivity pattern of Pseudomonas fluorescens after biofield treatment. J Infect Dis Ther 3: 222.

14. Neuman MR (2000) Biopotential electrodes. The biomedical engineering handbook. ( $2^{\text {nd }}$ edn), Boca Raton, CRC Press LLC, USA.

15. Rubik B (2002) The biofield hypothesis: its biophysical basis and role in medicine. J Altern Complement Med 8: 703-717.

16. Thomas $\mathrm{AH}$ (2012) Hidden in plain sight: The simple link between relativity and quantum mechanics. Swansea, UK

17. National Center for Complementary and Alternative Medicine. CAM Basics.

18. Movaffaghi Z, Farsi M (2009) Biofield therapies: biophysical basis and biological regulations? Complement Ther Clin Pract 15: 35-37.

19. Trivedi MK, Nayak G, Patil S, Tallapragada RM, Latiyal O (2015) Studies of the atomic and crystalline characteristics of ceramic oxide nano powders after bio field treatment. Ind Eng Manage 4: 161

20. Trivedi MK, Patil S, Nayak G, Jana S, Latiyal O (2015) Influence of biofield treatment on physical, structural and spectral properties of boron nitride. J Material Sci Eng 4: 181.

21. Sances F, Flora E, Patil S, Spence A, Shinde V (2013) Impact of biofield treatment on ginseng and organic blueberry yield. Agrivita J Agric Sci 35: 22-29.

22. Lenssen AW (2013) Biofield and fungicide seed treatment influences on soybean productivity, seed quality and weed community. Agricultural Journal 83: $138-143$.

23. Trivedi MK, Patil S, Shettigar H, Bairwa K, Jana S (2015) Phenotypic and biotypic characterization of Klebsiella oxytoca: An impact of biofield treatment. J Microb Biochem Technol 7: 203-206.

24. http://webbook.nist.gov/cgi/cbook.cgi?ID=C62533\&Mask=200\#Mass-Spec

25. http://webbook.nist.gov/cgi/cbook.cgi?ID=C106401\&Mask=200\#Mass-Spec

26. Eggenkamp H (2014) The geochemistry of stable chlorine and bromine isotopes. Advances in Isotope Geochemistry, Springer-Verlag, Heidelberg 172. 